\title{
Genotoxic effects in occupational exposure to formaldehyde: A study in anatomy and pathology laboratories and formaldehyde-resins production
}

\author{
Susana Viegas ${ }^{1,3^{*}}$, Carina Ladeira ${ }^{2,3}$, Carla Nunes ${ }^{3}$, Joana Malta-Vacas ${ }^{4}$, Mário Gomes ${ }^{5}$, Miguel Brito ${ }^{4}$,
} Paula Mendonça ${ }^{2}$, João Prista ${ }^{6}$

\begin{abstract}
Background: According to the Report on Carcinogens, formaldehyde ranks $25^{\text {th }}$ in the overall U.S. chemical production, with more than 5 million tons produced each year. Given its economic importance and widespread use, many people are exposed to formaldehyde environmentally and/or occupationally. Presently, the International Agency for Research on Cancer classifies formaldehyde as carcinogenic to humans (Group 1), based on sufficient evidence in humans and in experimental animals. Manyfold in vitro studies clearly indicated that formaldehyde can induce genotoxic effects in proliferating cultured mammalian cells. Furthermore, some in vivo studies have found changes in epithelial cells and in peripheral blood lymphocytes related to formaldehyde exposure.
\end{abstract}

Methods: A study was carried out in Portugal, using 80 workers occupationally exposed to formaldehyde vapours: 30 workers from formaldehyde and formaldehyde-based resins production factory and 50 from 10 pathology and anatomy laboratories. A control group of 85 non-exposed subjects was considered. Exposure assessment was performed by applying simultaneously two techniques of air monitoring: NIOSH Method 2541 and Photo lonization Detection equipment with simultaneously video recording. Evaluation of genotoxic effects was performed by application of micronucleus test in exfoliated epithelial cells from buccal mucosa and peripheral blood lymphocytes.

Results: Time-weighted average concentrations not exceeded the reference value $(0.75 \mathrm{ppm})$ in the two occupational settings studied. Ceiling concentrations, on the other hand, were higher than reference value (0.3 ppm) in both. The frequency of micronucleus in peripheral blood lymphocytes and in epithelial cells was significantly higher in both exposed groups than in the control group $(p<0.001)$. Moreover, the frequency of micronucleus in peripheral blood lymphocytes was significantly higher in the laboratories group than in the factory workers $(p<0.05)$. A moderate positive correlation was found between duration of occupational exposure to formaldehyde (years of exposure) and micronucleus frequency in peripheral blood lymphocytes $(r=0.401$; $p<0.001)$ and in epithelial cells $(r=0.209 ; p<0.01)$.

Conclusions: The population studied is exposed to high peak concentrations of formaldehyde with a long-term exposure. These two aspects, cumulatively, can be the cause of the observed genotoxic endpoint effects. The association of these cytogenetic effects with formaldehyde exposure gives important information to risk assessment process and may also be used to assess health risks for exposed workers.

\footnotetext{
* Correspondence: susana.viegas@estesl.jpl.pt

'Environmental Health Department. Escola Superior de Tecnologia da Saúde

de Lisboa - Instituto Politécnico de Lisboa. Lisbon, Portugal

Full list of author information is available at the end of the article
} 


\section{Background}

Formaldehyde $\left(\mathrm{CH}_{2} \mathrm{O}\right)$, the most simple and reactive of all aldehydes, is a colorless, reactive and readily polymerizing gas at room temperature [1]. It has a pungent suffocating odor that is recognized by most human subjects at concentrations below $1 \mathrm{ppm}$ [2].

According to the Report on Carcinogens, formaldehyde (FA) ranks $25^{\text {th }}$ in the overall U.S. chemical production, with more than 5 million tons produced each year [3]. FA annual production rises up to 21 million tons worldwide and it has increased in China, for example, in the recent years, with 7,5 million tons produced in 2007. Given its economic importance and widespread use, many people are exposed to FA environmentally and/or occupationally [4]. According to the International Information System on Occupational Exposure to Carcinogens (CAREX), in the period between 1990 and 1993, 36,000 workers were occupationally exposed to FA in Portugal [5].

Occupational exposure involves not only workers in direct production of FA and products containing it, but also in industries utilizing these products, such as those related with construction and household [1]. The most extensive use of FA is in production of resins with urea, phenol and melamine, and also polyacetal resins. These products are used as adhesives in manufacture of particle-board, plywood, furniture and other wood products [2]. FA is also used in cosmetics composition and has an important application as a disinfectant and preservative, reason why relevant workplace exposure may also occur in pathology and anatomy laboratories and in mortuaries $[1,2,6]$.

Human studies have shown that chronic exposure to FA by inhalation is associated with eye, nose and throat irritation [7]. Mostly important, several studies report a carcinogenic effect in humans after chronic exposure to $\mathrm{FA}$, in particular an increased risk for nasopharyngeal cancer [8-12]. Since 2006, International Agency for Research on Cancer (IARC) classifies FA as carcinogenic to humans (Group 1), based on sufficient evidence in humans and in experimental animals [2]. IARC also concluded that there is a "strong but not sufficient evidence for a causal association between leukemia and occupational exposure to formaldehyde".

With actual scientific evidence we can conclude that, regarding to risk estimation, local toxic effects at site of first contact seem to be the most relevant health effects $[2,7,13]$.

Manifold in vitro studies clearly indicated that FA can induce genotoxic effects in proliferating cultured mammalian cells [2]. Furthermore, some in vivo studies detected changes in epithelial cells (oral and nasal) and in peripheral lymphocytes related to FA exposure $[13,14]$.
Frequency of micronucleus (MN) in buccal and/or nasal mucosa cells is being used to investigate local genotoxicity. According to reports concerning experimental genotoxicity studies, $\mathrm{MN}$ are the most sensitive genetic endpoints for detection of FA induced genotoxicity [15]. Thus, MN test with exfoliated cells could be a powerful tool for detection of local genotoxic effects in humans, which is fundamental for hazard identification and risk estimation [13].

MN in peripheral blood lymphocytes has been extensively used to evaluate the presence and extend of chromosome damage in human populations exposed to genotoxic agents. As advantages, this $\mathrm{MN}$ test provides a reliable measure of chromosomal breakage and loss at lower cost and more easily than chromosomal aberrations. Moreover, the availability of cytokinesis-block technique eliminates potential background caused by effects on cell division kinetics [16].

The goal of this study is to contribute to the investigation of genotoxic effects in workers occupationally exposed to FA.

\section{Methods \\ Subjects}

This study was carried out in Portugal, in 80 workers occupationally exposed to FA vapors: 30 workers from FA and FA-based resins production factory and 50 from 10 pathology and anatomy laboratories. A control group of 85 non-exposed subjects was considered. All subjects were provided with the protocol and with the consent form, which they read and signed.

Health conditions, medical history, medication and lifestyle factors for all studied individuals, as well as information related to working practices (such as years of employment) were obtained through a standard questionnaire.

\section{Environmental Monitoring of FA exposure}

Exposure assessment was performed by applying simultaneously two different methods.

In one of the methods, environmental samples were obtained by personal air sampling with low flow pumps during a typical working day. Sampling time was 6 to 8 hours. FA levels were measured by Gas Chromatography (GC) analysis and time-weighted average $\left(\mathrm{TWA}_{8 \mathrm{~h}}\right.$ ) estimated according to the National Institute of Occupational Safety and Health method (NIOSH 2541) [17].

The other method was aimed to measure ceiling values of FA using Photo Ionization Detection (PID) equipment (11.7 eV lamps) with simultaneously video recording. Measures were performed in each task and instantaneous values for concentration were obtained on a per second basis. This method permits to establish a 
relation between worker activities and ceiling values and allows also determining the major emission sources [18].

\section{Micronucleus Test}

Evaluation of genotoxic effects was performed by application of MN test in exfoliated cells from buccal mucosa and peripheral blood lymphocytes. Heparinized venous blood and exfoliated cells (buccal mucosa cells) were collected between 10 a.m. and 12 p.m., from each subject, and were processed for each test. All samples were coded and analyzed under blind conditions. The criterion of scoring the MN in lymphocytes is described in "The Human Micronucleus Project" and the buccal cells is described by Tolbert et al. $[19,20]$.

\section{Buccal mucosa micronucleus test}

Endobrush was used to collect cells from the buccal mucosa. Exfoliated cells were smeared onto the slides and fixed with Mercofix ${ }^{\circ}$ The standard protocol used was Feulgen staining technique without counterstain. Two thousand cells were scored from each individual by four independent observers. Only cells containing intact nuclei that were not clumped or overlapped were included in the analysis.

\section{Peripheral Lymphocyte micronucleus test}

From each subject a blood specimen $(10 \mathrm{~mL})$ was collected using heparin as anticoagulant. The samples were kept refrigerated and processed within 6 hours of the blood collection. Lymphocytes were isolated using Ficoll-Paque gradient and placed in RPMI 1640 culture medium with L-glutamine and phenol red added with $10 \%$ inactivated fetal calf serum, $50 \mu \mathrm{g} / \mathrm{mL}$ streptomycin $+50 \mathrm{U} / \mathrm{mL}$ penicillin and $10 \mu \mathrm{g} / \mathrm{mL}$ phytohaemagglutinin. Duplicate cultures from each subject were incubated at $37^{\circ} \mathrm{C}$ in a humidified $5 \% \mathrm{CO}_{2}$ incubator for 44 hours. Cytochalasin-b $6 \mu \mathrm{g} / \mathrm{mL}$ was added to cultures. After 28 hours of incubation, cells were spun onto microscope slides using a cytocentrifuge. Smears were air-dried and double stained with May-GrünwaldGiemsa and mounted with Entellan'.

A total of 1000 binucleated cells with well-preserved cytoplasm were examined for each donor. The frequencies of binucleated cells with $\mathrm{MN}$ were determined analyzing 1,000 binucleate lymphocytes from two slides for each subject.

\section{Statistical Analysis}

Differences between groups (exposed workers and controls) were analyzed with $t$-Student and Proportion tests, in order to evaluate if basic characteristics of these 2 groups could be considered equivalent [20].

Association between quantitative variables was tested using correlation coefficient tests (Pearson or Spearman according with their probability distributions). Statistical analysis was performed with SPSS for Windows statistical package, version 17.0, and significance level was defined as $5 \%$, for all inference studies.

\section{Results}

\section{Characteristics of the studied population}

The characterization of the population studied is summarized in Table 1. Controls and exposed workers did not differ significantly in age and in smoking habits. Only for gender distribution a significant difference was found between the two groups $(p=0.002)$, due to the larger number of women in the control group.

None of the individuals presented relevant information about health conditions, medical history, medication and lifestyle factors that could influence the results of $\mathrm{MN}$ test.

\section{FA exposure levels}

FA exposure levels obtained by two methods (NIOSH 2541 for average concentrations - $\mathrm{TWA}_{8} \mathrm{~h}$ and Photo Ionization Detection method for ceiling concentrations C) are shown in Table 2.

Time-weighted average concentrations $\left(\mathrm{TWA}_{8 \mathrm{~h}}\right.$ ) have not exceeded the Occupational Safety and Health Administration (OSHA) reference value (0.75 ppm). On the other hand, ceiling concentrations were higher than American Conference of Industrial Hygienists (ACGIH) reference value $(0.3 \mathrm{ppm})$ in both occupational settings.

Mean FA ceiling levels are higher in pathology and anatomy laboratories than in resins factory. In this setting, 83 tasks were studied and highest exposure level was observed during macroscopic examination of FApreserved specimens. Moreover, 93\% of studied tasks obtained ceiling levels higher than reference value $(0.3 \mathrm{ppm})$. Pathologists were the professional group

Table 1 Characterization of the studied population

\begin{tabular}{lccc}
\hline & Control Group & Exposed Group & P value \\
\hline Number of subjects & 85 & 80 & \\
\hline Gender & & & \\
$\quad$ Male & $31(36.6 \%)$ & $48(60.0 \%)$ & 0.002 \\
$\quad$ Female & $54(63.5 \%)$ & $32(40.0 \%)$ & \\
\hline Age (years) & & & \\
$\quad$ Range & $20-55$ & $19-56$ & \\
$\quad$ Mean & 33.87 & 35.74 & 0.180 \\
St. Deviation & 8.262 & 9.470 & 0.024 \\
\hline Smoking status & & & \\
$\quad$ Non-smokers & $59(69.4 \%)$ & $55(68.8 \%)$ & 0.927 \\
$\quad$ Smokers & $26(30.6 \%)$ & $25(31.3 \%)$ & \\
\hline Years of exposure & & & \\
$\quad$ Range & $-1-35$ &
\end{tabular}


Table 2 FA exposure in the two occupational settings

\begin{tabular}{lcc}
\hline & Factory & Laboratories \\
\hline Exposure duration (Years) & $1-27$ & $1-33$ \\
$\quad$ Range & 6.2 & 14.5 \\
Mean & 6.74 & 9.12 \\
$\quad$ St. Deviation & 7 & 7 \\
\hline Working hours/day (h) & 2 & 29 \\
\hline Number of Samples (TWA measures) & & \\
\hline FA exposure level (TWA h $^{\text {) }}(\mathrm{ppm})$ & $0.20-0.22$ & $0.05-0.51$ \\
$\quad$ Range & 0.21 & 0.28 \\
$\quad$ Mean & $0.003-1.04$ & $0.02-5.02$ \\
\hline FA ceiling concentration $(\mathrm{ppm})$ & 0.52 & 2.52 \\
$\quad$ Range &
\end{tabular}

exposed to the highest ceiling concentration values (Table 3).

Exposure has been studied in normal conditions of operation, namely with ventilation dispositives connected and workers not using protective masks.

\section{Micronucleus Test}

The frequency of $\mathrm{MN}$ in occupationally exposed workers was significantly higher than in the control group, both in peripheral blood lymphocytes $(p<0.001)$ and in epithelial buccal cells $(p<0.001)$ (Table 4$)$.

When analyzing each occupational setting separately, we found significant differences in $\mathrm{MN}$ frequencies in peripheral blood lymphocytes $(p<0.001)$ and in epithelial buccal cells $(p<0.005)$ between the laboratories and control groups. Concerning the factory group, significant differences in $\mathrm{MN}$ frequencies were only detected in epithelial buccal cells $(p<0.001)$.

Finally, we compared $\mathrm{MN}$ frequencies between the two exposed groups and found that $\mathrm{MN}$ frequency in peripheral blood lymphocytes was significantly higher in the laboratories group $(p<0.005)$, but respecting to epithelial buccal cells there was no significant difference between them $(p=0.108)$.
There was no significant difference in the frequency of $\mathrm{MN}$, both in epithelial cells and peripheral lymphocyte tested for smoking habits $(p=0.31 ; p=0.99)$ and for gender $(p=0.13 ; p=0.47)$.

Age was found to have a weak positive correlation $(r=$ 0.194; $\mathrm{p}<0.05$ ) with $\mathrm{MN}$ frequency in peripheral blood lymphocytes and a week negative correlation $(r=-0.168$; $\mathrm{p}<0.05)$ with $\mathrm{MN}$ frequency in epithelial cells. A moderate positive correlation was found between duration of occupational exposure to FA (years of exposure) and frequency of $\mathrm{MN}$ in peripheral blood lymphocytes $(\mathrm{r}=0.401 ; p<0.05)$ and in epithelial cells $(\mathrm{r}=0.209$; $p<0.05)$ (Table 5).

There was no significant difference $(p>0.05)$ in the frequency of $\mathrm{MN}$ in both peripheral blood lymphocytes and epithelial cells tested for smoking habits $(p=0.31$; $p=0.99)$ and for gender $(p=0.13 ; p=0.47)$.

\section{Discussion}

As indicated by several studies $[6,21,22]$ exposure assessment in present investigation identified that both groups of workers (factory and laboratory) were exposed to high peak FA concentrations.

The importance of this consideration lies in the fact that health effects (cancer) linked to FA exposure are more related with peaks of high concentrations than with long time exposure at low levels [2,23]. The choice of exposure metric should be based on the most biologically relevant exposure measure in order to diminish misclassification of exposure, thus leading to attenuated exposure-response relationships [24]. Moreover, exposures of short duration (peaks) are of special concern, because they produce an elevated dose rate at target tissues and organs, potentially altering metabolism, overloading protective and repair mechanisms and amplifying tissue responses [24,25].

Considering this, Pyatt et al. (2008) pointed out, as a limitation in most epidemiological studies, the lack of data about exposure to peak concentrations. Therefore, in those studies, health effects resulting from

Table 3 FA Ceiling values (ppm) according to places of work, tasks and exposed workers

\begin{tabular}{cccc}
\hline Places of work & Tasks & Ceiling Values (ppm) & Exposed Workers \\
\hline Factory Resins production & Sample collect (Reactors) & 1.09 & Reactor operators \\
\hline Factory Impregnation & Machine operation & 0.52 & Impregnation machine operators \\
\hline Factory Quality Laboratory & Quality control & 5.02 & Quality Technicians \\
\hline Pathology and anatomy laboratories & Macroscopic examination & 0.95 & Pathologist \\
\hline Pathology and anatomy laboratories & Disposal of specimen and used solutions & 2.51 & Technicians and Assistants \\
\hline Pathology and anatomy laboratories & Jar filling & Assistants & 1.28 \\
\hline Pathology and anatomy laboratories & Specimen wash & Technicians \\
\hline Pathology and anatomy laboratories & Biopsy & Technicians \\
\hline
\end{tabular}


Table 4 Frequency of MN in the studied population

\begin{tabular}{ccccc}
\hline & Controls & Factory & Pathology and anatomy laboratories & Total \\
\hline $\begin{array}{c}\text { MN PBL }{ }^{1} \\
\text { Mean } \pm \text { Std. Dev }\end{array}$ & $1.17 \pm 1.95$ & $1.76 \pm 2.07$ & $3.70 \pm 3.86$ & $2.97 \pm 3.42$ \\
\hline $\begin{array}{c}\text { MN EBC } \\
\text { Mean } \pm \text { Std. Dev }\end{array}$ & $0.13 \pm 0.48$ & $1.27 \pm 1.55$ & & $0.64 \pm 1.74$ \\
\hline
\end{tabular}

${ }^{1}$ peripheral blood lymphocytes (cytochalasin-B (binucleated) assay

2 epithelial buccal cells

occupational exposure to FA are associated to exposure exclusively based on time-weighted average concentrations [23]. The only two studies concerning the association between exposure to FA and nasopharyngeal cancer that presented data on exposure to ceiling concentrations obtained higher relative risk values compared with the other studies $[1,12,26]$.

Moreover, other groups also suggested ceiling concentrations as the most important exposure metric, when attempting to define the relative risk of myeloid leukaemia in workers exposed to FA [1,27-29].

The present results obtained in the laboratories, evidence a difference between the two exposure metrics (0.28 ppm for TWA $_{8 \mathrm{~h}}$ and $2.52 \mathrm{ppm}$ for ceiling level). These results are in good agreement with previous ones reported by Shaham et al. [30]. A difference of the same order of magnitude was described in 14 pathology laboratories $(0.4 \mathrm{ppm}$ for TWA and 2.24 ppm for ceiling level).

Each one of these results would lead to different conclusions about exposure assessment and, consequently, to a different risk assessment and, though, claim our attention for the importance of exposure metric selection. For FA occupational exposure, ceiling concentrations might be a better strategy to evaluate exposure and to develop risk assessment once very high exposures over short periods are missed by $\mathrm{TWA}_{8 \mathrm{~h}}$ method and, in fact, they are important to know the real risk for health $[23,31]$. Therefore, as in other investigations $[33,34]$, it is possible to conclude that when measuring only $\mathrm{TWA}_{8} \mathrm{~h}$ poor information is obtained, and the

Table 5 Correlation analysis between genotoxic endpoints and age and years of exposure (Spearman's test)

\begin{tabular}{|c|c|c|}
\hline Genotoxic endpoints & Age & Years of Exposure \\
\hline & $r=0.194$ & $r=0.401$ \\
\hline$M N P B L^{1}$ & $p=0.013$ & $p=0.0$ \\
\hline & $r=-0.168$ & $r=0.209$ \\
\hline$M N E B C^{2}$ & $p=0.031$ & $p=0.008$ \\
\hline
\end{tabular}

\footnotetext{
1 peripheral blood lymphocytes (cytochalasin-B (binucleated) assay)

2 epithelial buccal cells
}

method is of less utility to identify processes that should be targeted for controls.

Results indicate macroscopic examination of anatomical specimens FA-preserved as the task involving exposure to the highest values. This occurs because precision and good visibility is required and as a consequence pathologists must lean over the specimen with consequent increase of proximity to FA emission sources. Studies developed by Goyer et al. and Orsière et al. support that proximity to impregnated specimens promotes higher exposure to FA $[6,22]$.

In factory, the task of collecting samples from resins reactor present the higher exposure, because the reactors are consider the units with larger emissions [6,32]. Furthermore, the sampling process is still manual in the factory studied.

It is important to notice that the information about exposure determinants, emission sources and exposed workers was only possible because video recording could be performed. This resource gives the opportunity to directly relate performance with exposure $[18,35,36]$.

FA genotoxicity is confirmed in a variety of experimental systems ranging from bacteria to rodents in vivo [37]. Although the findings from in vivo animal studies may provide a basis for extrapolation to humans, cytogenetic assays in humans have been conflicting, sometimes with contradictory outcomes [38]. Nevertheless, our results showed a significant increase in MN frequency in epithelial cells and in lymphocytes of exposed individuals compared with controls.

Biological evidence of toxicity on distant-site such as peripheral lymphocytes and bone marrow is still controversial $[2,39]$. Some authors have argued that it is biologically implausible for FA to cause leukaemia as FA is unlikely to reach the bone marrow and cause toxicity. Due to its highly reactive nature and rapid metabolism, there is no evidence that it can damage stem and progenitor cells (the target cells for leukemogenesis). Also, there is no credible experimental animal model for FAinduced leukaemia $[40,41]$. However, Zhang et al. hypothesize that FA may act on bone marrow directly or, alternatively, may cause leukaemia by damaging the hematopoietic stem or early progenitor cells that are 
located in the circulating blood or nasal passages, which would then travel to bone marrow and become leukemic stem cells $[1,29]$. Nevertheless, our findings are consistent with other previous studies on epithelial cells and also on peripheral lymphocytes [42-44]. Suruda et al. reported that low-level exposure to FA was associated with cytogenetic changes in buccal epithelial cells and in blood lymphocytes in mortician students [14]. Our results in blood lymphocytes can be an indication that cytogenetic effects can be found in tissues distant from the area of initial contact (nasopharyngeal) and even reach the bone marrow and cause toxicity, supporting the thesis of Zhang and colleagues [1,29].

A significant positive correlation between $\mathrm{MN}$ frequency (both in peripheral blood lymphocytes and in epithelial buccal cells) and the duration of FA exposure (years of employment) was found (Table 4). This indicates that, together with peak contacts, exposure duration also has relevance for the development of health effects. Furthermore, in our study, long-term exposure to high levels of FA was noted particularly in pathology and anatomy laboratory workers (exposure duration mean of 14.5 years), fact that may at least contribute to explain the higher frequency of $\mathrm{MN}$ in peripheral blood lymphocytes in this group when compared to the factory group (Table 4). Regarding the influence of age, a positive correlation was found with MN frequency in peripheral blood lymphocytes (Table 5). MN frequencies tend to rise with age because of the progressive increase in spontaneous chromosome instability and the loss of efficiency in DNA repair mechanisms, which may result in accumulation of genetic lesions with increasing age $[22,45]$. On the other hand, for MN frequency in epithelial buccal cells, a negative correlation was found (Table 5). This can possibly be explained by the fact that cells of buccal mucosa have a steady and rapid turnover, and therefore accumulation of genotoxic effects becomes difficult [13].

No significant differences were obtained in $\mathrm{MN}$ frequencies between women and men (both in peripheral blood lymphocytes and epithelial buccal cells). However, in other studies an increase in $\mathrm{MN}$ frequencies in women was found. Current knowledge on the effect of gender on genetic damage determines a 1.5 -fold greater $\mathrm{MN}$ frequency in females than in males $[19,45]$, witch can be explained by preferential aneugenic events involving the X-chromossome. Surralés et al. reported an excessive overrepresentation of this chromosome in micronucleic lymphocytes cultured from women [46].

Tobacco smoke contains a high number of mutagenic and carcinogenic substances and is causally linked to an elevated incidence of several forms of cancers [47]. Hence, smoking is an important variable to consider in biomonitoring studies and, particularly in this study since FA is present in tobacco smoke [2]. The effect of tobacco smoking on $\mathrm{MN}$ frequency in human cells has been object of study. In most reports the results were unexpected, as in many instance smokers had lower frequencies of $\mathrm{MN}$ than non-smokers [22,48]. In the present study no significant differences were found in $\mathrm{MN}$ (peripheral blood lymphocytes and epithelial buccal cells) between smokers and non-smokers. These findings are similar to results obtained in the study of Bonassi $e t$ al., [48]. These authors recommend that quantitative data about smoking habit should be collected because the sub-group of heavy smokers ( $\geq 30$ cigarettes per day) can influence the results. For notice, the questionnaire results of this study revealed no heavy smokers in these workers groups.

\section{Conclusions}

In conclusion, the population studied is exposed to high ceiling concentrations (peaks) of FA with a long-term exposure. These two aspects, cumulatively, can be the cause for the increase in $\mathrm{MN}$ frequencies in lymphocytes and in epithelial buccal cells.

Results obtained suggest that preventive and protective measures must be applied in order to reduce occupational exposure to this chemical agent in these two occupational settings and, subsequently, to prevent adverse effects on workers health.

\section{Acknowledgements}

This work was supported by Portuguese Authority for Work Conditions (ACT: http://www.act.gov.pt/). Project reference: 075MNA/06.

\section{Author details}

${ }^{1}$ Environmental Health Department. Escola Superior de Tecnologia da Saúde de Lisboa - Instituto Politécnico de Lisboa. Lisbon, Portugal. ${ }^{2}$ Anatomy and Pathology Department. Escola Superior de Tecnologia da Saúde de Lisboa Instituto Politécnico de Lisboa. Lisbon, Portugal. ${ }^{3} \mathrm{CIESP}$ - Centro de Investigação e Estudos em Saúde Pública (ENSP/UNL) ENSP - Escola Nacional de Saúde Pública - Universidade Nova de Lisboa. Lisbon, Portugal. " Biology Department. Escola Superior de Tecnologia da Saúde de Lisboa - Instituto Politécnico de Lisboa. Lisbon, Portugal. ${ }^{5}$ Chemistry Department. Escola Superior de Tecnologia da Saúde de Lisboa - Instituto Politécnico de Lisboa. Lisbon. Portugal and REQUIMTE/CQFB, Faculty of Sciences and Technology, Universidade Nova de Lisboa and SINTOR-UNINOVA, Monte de Caparica, Portugal. ${ }^{6}$ Environmental and Occupational Health Department and CIESP Centro de Investigação e Estudos em Saúde Pública (ENSP/UNL) ENSP Escola Nacional de Saúde Pública - Universidade Nova de Lisboa. Lisbon, Portugal.

\section{Authors' contributions}

SV conceived the idea and designed the study, and developed also formaldehyde exposure assessment. CL, PM, JMV and MB performed the MN tests. MG developed chemical analysis. CN performed the statistical data analyses. JP contributed to the study design and coordination. All authors have read and approved the final manuscript.

\section{Competing interests}

The authors declare that they have no competing interests.

Received: 5 April 2010 Accepted: 20 August 2010

Published: 20 August 2010 


\section{References}

1. Zhang L, Steinmaus C, Eastmond DA, Xin XK, Smith MT: Formaldehyde exposure and leukemia: A new meta-analysis and potential mechanisms. Mutat Res 2009, 681:150-168.

2. International Agency for Research on Cancer: Formaldehyde, 2Butoxyethanol and 1-tert-Butoxypropan-2-ol. Lyon: IARC 2006.

3. National Toxicology Program (NTP): Formaldehyde (Gas) CAS no. 50-00-0, 2005: report on carcinogens [Em linha] Washington, DC: National Institutes of Health, 112005 [http://ntp.niehs.nih.gov/ntp/roc/eleventh/profiles/s089form. pdf].

4. Nazaroff W, Coleman BK, Destaillats H, Hodgson AT, Liu D, Lunden MM, Singer BC, Weschler CJ: Indoor air chemistry: cleaning agents, ozone and toxic air contaminants Berkeley, CA: Air Resources Board, California Environmental Protection Agency 2006.

5. Kauppinen T, Toikkanen J, Pedersen D, Young R, Ahrens W, Boffetta P, Hansen J, Kromhout H, Maqueda Blasco J, Mirabelli D, de la Orden-Rivera V Pannett B, Plato N, Savela A, Vincent R, Kogevinas M: Occupational exposure to carcinogens in the European Union. Occup Environ Med 2000, 57:10-8.

6. Goyer N, Beaudry C, Bégin D, Bouchard M, Buissonnet S, Carrier G, Gely O, Gérin M, Lavoué J, Lefebvre P, Noisel N, Perrault G, Roberge B: Impacts d'un abaissement de la valeur d'exposition admissible au formaldéhyde: industries de fabrication de formaldéhyde et de résines à base de formaldéhyde Montréal: Institut de Recherche Robert-Sauvé en Santé et en Sécurité du Travail 2004

7. Herausgegeben von AS, Bernauer U, Madle $S$, Mielke H, Herbst U, RichterReichhelm HB, Appel KE, Gundert-Remy U: Assessment of the carcinogenicity of formaldehyde (CAS No. 50-00-00) Berlim: Bundesinstitut für Risikobewertung 2006.

8. Armstrong RW, Imrey PB, Lye MS, Armstrong MJ, Yu MC, Sani S: Nasopharyngeal carcinoma in Malaysian Chinese: occupational exposures to particles, formaldehyde and heat. Int J Epidemio/ 2000 29:991-998.

9. Vaughan TL, Stewart PA, Teschke K, Lynch CF, Swanson GM, Lyon JL, Berwick M: Occupational exposure to formaldehyde and wood dust and nasopharyngeal carcinoma. Occup Environ Med 2000, 57:376-384.

10. Hildesheim A, Dosemeci M, Chan CC, Chen CJ, Cheng YJ, Hsu MM, Chen IH, Mittl BF, Sun B, Levine PH, Chen JY, Brinton LA, Yang CS: Occupational exposure to wood, formaldehyde, and solvents and risk of nasopharyngeal carcinoma. Cancer Epidemiol Biomarkers Prev 2001, 10:1145-1153.

11. Coggon D, Harris EC, Poole J, Palmer KT: Extended follow-up of a cohort of British chemical workers exposed to formaldehyde. J Natl Cancer Inst 2003, 95:1608-1615.

12. Hauptmann $M$, Lubin JH, Stewart PA, Hayes RB, Blair A: Mortality from solid cancers among workers in formaldehyde industries. Am J Epidemiol 2004, 159:1117-1130

13. Speit G, Schmid O: Local genotoxic effects of formaldehyde in humans measured by the micronucleus test with exfoliated cells. Mutat Res 2006, 613:1-9.

14. Suruda A, Schulte $P$, Boeniger M, Hayes RB, Livingston GK, Steenland K, Stewart $P$, Herrick R, Douthit D, Fingerhut MA: Cytogenetic effects of formaldehyde exposure in students of mortuary science. Cancer Epidemiol Biomarkers Prev 1993, 2:453-460.

15. Merk O, Speit G: Significance of formaldehyde-induced DNA-protein crosslinks for mutagenesis. Environ Mol Mutagen 1998, 32:260-268.

16. Bonassi S, Fenech M, Lando C, Lin YP, Ceppi M, Chang WP, Holland N, Kirsch-Volders M, Zeiger E, Ban S, Barale R, Bigatti MP, Bolognesi C, Jia C, Di Giorgio M, Ferguson LR, Fucic A, Lima OG, Hrelia P, Krishnaja AP, Lee TK, Migliore L, Mikhalevich L, Mirkova E, Mosesso P, Müller WU, Odagiri Y, Scarffi MR, Szabova E, Vorobtsova I, Vral A, Zijno A: Human MicroNucleus Project: international database comparison for results with the cytokinesis-block micronucleus assay in human lymphocytes: I. Effect of laboratory protocol, scoring criteria, and host factors on the frequency of micronuclei. Environ Mol Mutagen 2001, 37:31-45.

17. National Institute for Occupational Safety and Health (NIOSH) Formaldehyde: method 2541 Cincinnati, OH: NIOSH, 4 1994, 2.

18. Mcglothlin J, Xu F, Vosciky J: Occupational exposure assessment and control using video exposure monitoring in the pharmaceutical industry. Proceedings of the International Scientific Conference IOHA 2005: 19-23 September South Africa 2005.
19. Fenech M, Chang WP, Kirsch-Volders M, Holland N, Bonassi S, Zeiger E: HUman MicronNucleus project: HUMN project: detailed description of the scoring criteria for the cytokinesis-block micronucleus assay using isolated human lymphocyte cultures. Mutat Res 2003, 534:65-75.

20. Dawson B, Trapp R: Basic and clinical biostatistics MacGraw-Hill Medical 1994

21. Shaham J, Bomstein Y, Gurvich R, Rashkovsky M, Kaufman Z: DNA-protein crosslinks and p53 protein expression in relation to occupational exposure to formaldehyde. Occup Environ Med 2003, 60:403-409.

22. Orsière T, Sari-Minodier I, larmarcovai G, Botta A: Genotoxic risk assessment of pathology and anatomy laboratory workers exposed to formaldehyde by use of personal air sampling and analysis of DNA damage in peripheral lymphociytes. Mutat Res 2006, 605:30-41.

23. Pyatt $D$, Natelson $E$, Golden R: Is inhalation exposure to formaldehyde a biological plausible cause of lymphohematopoietic malignancies? Regul Toxicol Pharmacol 2008, 51:119-133.

24. Preller L, Burstyn I, De Pater N, Kromhout H: Characteristics of Peaks of Inhalation Exposure to Organic Solvents. Ann Occup Hyg 2004, 48:643-652.

25. Smith T: In Studying peak exposure: toxicology and exposure statistics. Edited by: Marklund S. Stockholm: National Institute for Working Life; 2001:207-209, X2001 - Exposure assessment in epidemiology and practice..

26. Pinkerton LE, Hein MJ, Stayner LT: Mortality among a cohort of garment workers exposed to formaldehyde: an update. Occup Environ Med 2004, 61:193-200.

27. Collins JJ, Lineker GA: A review and meta-analysis of formaldehyde exposure and leukemia. Regul Toxicol Pharmacol 2004, 40:81-91.

28. Bosetti C, McLaughlin JK, Tarone RE, Pira E, La Vecchia C: Formaldehyde and cancer risk: a quantitative review of cohort studies through 2006. Ann Oncol 2008, 19:29-43.

29. Zhang $L$, Tang $X$, Rothman N: Occupational exposure to formaldehyde, hematotoxicity, and leukemia-specific chromosome changes in cultured myeloid progenitor cells. Cancer Epidemiology, Biomarkers \& Prevention 2010, 19:80-88

30. Shaham J, Gurvich R, Kaufman Z: Sister chromatid exchange in pathology staff occupationally exposed to formaldehyde. Mutation Research 2002, 514:1-2, 115-123.

31. Poirot $P$, Subra I, Gérardin F, Baudin V, Grossmann S, Héry M: Determination of short-term exposure with a direct reading photoionization detector. Ann Occup Hyg 2004, 48:75-84.

32. González Ferradás E: Formaldehido: toxicologia e impacto ambiental Madrid: Editorial MAPFRE 1986

33. Susi P, Schneider S: Database Needs for a Task-Based Exposure. Assessment Model for Construction. Appl Occup Environ Hyg 1995, 10:394-399.

34. Kromhout $\mathrm{H}$ : Design of measurement strategies for workplace exposures. Occup Environ Med 2002, 59:349-354.

35. Ryan TJ, Burroughs GE, Taylor K, Kovein RJ: Video exposure assessments demonstrate excessive laboratory formaldehyde exposures. Appl Occup Environ Hyg 2003, 18:450-457.

36. Rosén $G$, Andersson IM, Walsh PT, Clark RD, Säämänen A, Heinonen $K$ Riipinen $\mathrm{H}$, Pääkkönen $\mathrm{R}$ : A review of video exposure monitoring as an occupational hygiene tool. Ann Occup Hyg 2005, 49:201-217.

37. Speit $G$, Schütz $P$, Högel J, Schmid $O$ : Characterization of the genotoxic potencial of formaldehyde in V79 cells. Mutagenesis 22 2007, , 6: 387-394.

38. Pala M, Ugolini D, Ceppi M, Rizzo F, Maiorana L, Bolognesi C, Schilirò T, Gilli G, Bigatti P, Bono R, Vecchio D: Occupational exposure to formaldehyde and biological monitoring of Research Institute workers. Cancer Detection and Prevention 32 2008, 121-126.

39. Heck H, Casanova M: The implausibility of leukemia induction by formaldehyde: a critical review of the biological evidence on distant-site toxicity. Regul Toxicol Pharmacol 2004, 40:92-106.

40. Cole P, Axten C: Formaldehyde and leukemia: an improbable causal relationship. Regul Toxicol Pharmacol 2004, 40:107-112.

41. Golden R, Pyatt D, Shields PG: Formaldehyde as a potential human leukemogen: an assessment of biological plausibility. Crit Rev Toxicol 2006, 36:135-153.

42. Titenko-Holland N, Levine AJ, Smith MT, Quintana PJ, Boeniger M, Hayes R, Suruda A, Schulte P: Quantification of epithelial cell micronuclei by fluorescence in situ hybridization (FISH) in mortuary science students exposed to formaldehyde. Mutat Res 1996, 371:237-248. 
43. Ying CJ, Yan WS, Zhao MY, Ye XL, Xie H, Yin SY, Zhu XS: Micronuclei in nasal mucosa, oral mucosa and lymphocytes in students exposed to formaldehyde vapor in anatomy class. Biomed Environ Sci 1997, 10:451-455.

44. Burgaz S, Erdem O, Cakmak G, Erdem N, Karakaya A, Karakaya AE: Cytogenetic analysis of buccal cells from shoeworkers and pathology and anatomy laboratory workers exposed to $n$-hexane, toluene, methyl ethyl ketone and formaldehyde. Biomarkers 2002, 7:151-161.

45. Wojda A, Zietkiewicz E, Witt M: Effects of age and gender on micronucleus and chromosome nondisjunction frequencies in centenarians and younger subjects. Mutagenesis 2007, 22:195-200.

46. Surrallés J, Falck G, Norppa H: In vivo cytogenetic damage revealed by FISH analysis of micronuclei in uncultured human T lymphocytes. Cytogenet Cell Genet 1996, 75:151-154.

47. International Agency for Research on Cancer: Tobacco Habits Other Than Smoking Betel-Quid and Areca-Nut Chewing and Some Related Nitrosamines. Lyon: IARC 1985.

48. Bonassi S, Neri M, Lando C, Ceppi M, Lin YP, Chang WP, Holland N, KirschVolders M, Zeiger E, Fenech M, HUMN collaborative group: Effect of smoking habit on the frequency of micronuclei in human lymphocytes: results from the Human MicroNucleus project. Mutat Res 2003, 543:155-166.

49. Tolbert PE, Shy CM, Allen JW: Micronuclei and other nuclear anomalies in buccal smears: a field test in snuff users. Am J Epidemiol 1991, 134:840-850

doi:10.1186/1745-6673-5-25

Cite this article as: Viegas et al:: Genotoxic effects in occupational exposure to formaldehyde: A study in anatomy and pathology laboratories and formaldehyde-resins production. Journal of Occupational Medicine and Toxicology 2010 5:25.

\section{Submit your next manuscript to BioMed Central and take full advantage of:}

- Convenient online submission

- Thorough peer review

- No space constraints or color figure charges

- Immediate publication on acceptance

- Inclusion in PubMed, CAS, Scopus and Google Scholar

- Research which is freely available for redistribution

Submit your manuscript at www.biomedcentral.com/submit
Biomed Central 